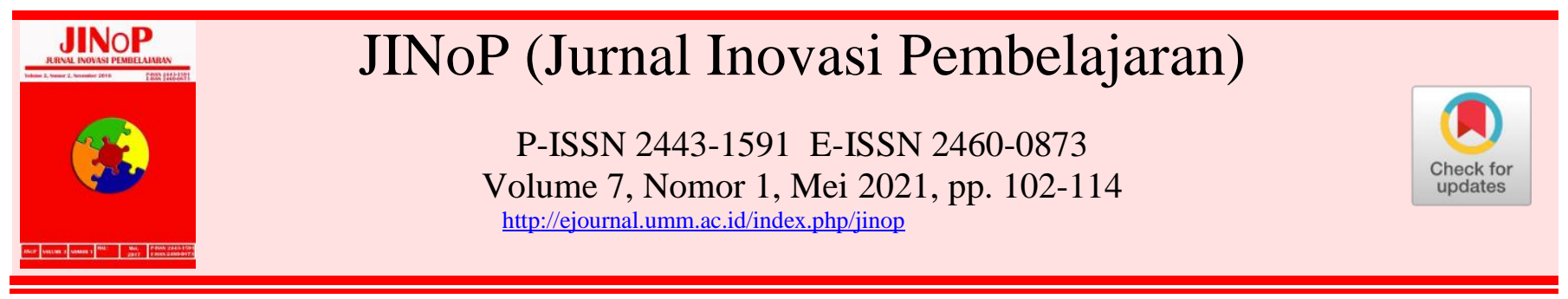

\title{
Analisis interpretasi matematis dalam mini riset mahasiswa melalui pembelajaran berbasis riset
}

\author{
Adi Slamet Kusumawardana ${ }^{1)^{*}}$, Mayang Dintarini ${ }^{2)}$ \\ ${ }^{1}$ Program Studi Pendidikan Matematika, Fakultas Keguruan dan Ilmu Pendidikan, Universitas \\ Muhammadiyah Malang, Jl. Raya Tlogomas No. 246, Kota Malang, Indonesia. \\ ${ }^{2}$ Program Studi Pendidikan Matematika, Fakultas Keguruan dan Ilmu Pendidikan, Universitas \\ Muhammadiyah Malang, J1. Raya Tlogomas No. 246, Kota Malang, Indonesia \\ adikusuma@umm.ac.id*; mayangdintarini@umm.ac.id \\ *Penulis Koresponden
}

ABSTRAK
Ilmu Statistika dipelajari pada banyak bidang studi termasuk Ilmu Pemerintahan Universitas
Muhammadiyah Malang (UMM) Tapi pada realitanya, mahasiswa program studi Ilmu
Pemerintahan UMM masih banyak yang kurang memahami materi dan masih kesulitan dalam
mengaplikasikan metode statistika, sehingga perlu diberikan pembelajaran berbasis mini riset dan
kemudian dideskripsikan kemampuan interpretasinya. Tujuan penelitian ini adalah untuk
mendeskripsikan kemampuan interpretasi mahasiswa dalam mini riset pada pembelajaran
berbasis riset. Penelitian menggunakan metode deskriptif kualitatif. Sampel penelitian diambil
berdasarkan teknik Purposive Sampling dengan pertimbangan mahasiswa yang mampu
menyelesaikan seluruh dan diambil 1 orang mahasiswa yang melakukan pembelajaran berbasis
mini riset. Hasil laporan mahasiswa dianalisis sesuai indikator kemampuan interpretasi. Hasil
penelitian penelitian ini menunjukkan bahwa penerapan pembelajaran berbasis riset pada mata
kuliah statistika membawa dampak positif pada kemampuan interpretasi matematis mahasiswa.
Hal tersebut terlihat dari ketercapaian indikator representasi matematis yang ditemukan pada mini
riset yang dilakukan subjek 1 di kelas. Namun terdapat beberapa hal yang perlu ditingkatkan
dalam mini riset yang dilakukan subjek 1, yaitu pada indikator menyajikan masalah dan
penyelesaiannya dalam bentuk lain. Khususnya pada deskriptor menuliskan notasi dalam bentuk
lain serta mengkomunikasikan notasi sesuai dengan idenya.
Kata Kunci: Interpretasi Matematis; Mini Riset; Statistika

\section{ABSTRACT}

Statistics are studied in many fields of study including in Governmental Science, University of Muhammadiyah Malang (UMM). However, in reality, many UMM Government Science students do not understand the material and still have difficulty applying statistical methods, so it is necessary to provide mini research-based learning and analysis of interpretation abilities. The purpose of this research was to analyze students' interpretative abilities in a mini research on research-based learning. The research used a qualitative descriptive method. The research sample consisted of 1 student who carried out mini research-based learning. The results of student's reports were analyzed according to the indicators of interpretation ability. The result of the research indicated that the application of research-based learning in statistics subjects has a positive impact on students' mathematical interpretation abilities can be seen from the achievement of the mathematical representation indicators found in the mini-research conducted by subject 1 in class. However, several things need to be improved in the mini research conducted by subject 1 , namely presenting problems and solving them in other forms. The descriptor wrote the notation in other forms and communicates the notation according to the idea.

Keywords: Mathematical Interpretation; Mini Research; Statistics 
diunggah: 2019-11-26, direvisi:2021-05-20, diterima: 2021-05-22, dipublikasi: 2021-05-25

Copyright (c) 2021 Kusumawardana et al

This is an open access article under the CC-BY license

Cara sitasi: Kusumawardhana, A. S., \& Dintarini, M. (2021). Analisis interpretasi matematis dalam mini riset mahasiswa melalui pembelajaran berbasis riset. JINoP (Jurnal Inovasi Pembelajaran), 7(1), 102-114. https://doi.org/10.22219/jinop.v7i1.10416

\section{PENDAHULUAN}

Ilmu statistika banyak dipelajari dan diaplikasikan pada masa kini (Wells \& Nemire, 2017). Ilmu Statistika dalam dunia perguruan tinggi disajikan dalam bentuk mata kuliah statistika dan dirancang untuk mempelajari konsep dasar statistika, metode statistika, dan aplikasinya (Dewi et al., 2020; Firmansyah, 2017; Krisdiana, 2016). Aplikasi statistika banyak ditemui tidak hanya pada bidang eksakta saja tetapi juga banyak digunakan pada bidang non eksakta seperti bidang sosial dan pendidikan. Statistika dipelajari pada bidang eksakta seperti bidang Teknik, Ekonomi, Sains, dan Kesehatan berupa mata kuliah khusus statistika aplikatif, seperti Statistika Teknik yang membahas aplikasi statistika pada bidang Teknik (Syafitri \& Astuti, 2019; Syaviera Nova \& Sastrawijaya, 2017); Ekonometrika dalam bidang ekonomi yang berisi kajian antara ekonomi, model statistika, dan analisis ekonomi publik (Kusrini \& Novandalina, 2018; Maryati, 2018; Wikayanti et al., 2020); lalu Statistika Deskriptif dan Inferensia yang umum diajarkan pada bidang Sains (Nurizzati, 2014; Sukmawati, 2018); dan Mata kuliah Biostatistika yang membahas tentang penggunaan statistika pada eksperimen dan riset di bidang kesehatan (Wahyuningrum, 2021). Sementara pada bidang non eksakta, Statistika umumnya mempelajari tentang metode statistika, cara mengolah data penelitian, penentuan metode analisis, penyajian data, pengujian hipotesis, dan pengambilan keputusan pada penelitian (Numan, 2019; Rizana, 2020; Sowanto et al., 2019). Pada perkuliahan di bidang non eksakta seperti sosial dan pendidikan, statistika merupakan mata kuliah yang sangat penting bagi mahasiswa, baik mahasiswa S1 maupun S2 (Suandika et al., 2020), karena konsep dan metode statistika diperlukan mahasiswa dalam merancang mini riset, menyusun instrument penelitian, dan menyusun laporan penelitian yang dapat berupa skripsi atau tesis . Sehingga hal di atas menunjukkan bahwa mata kuliah statistika merupakan mata kuliah yang penting dan esensial dalam banyak bidang (Puspananda \& Rahmawati, 2020; Puspitasari, 2016; Sanusi, 2017).

Bidang sosial dan politik tak lepas dari aspek statistika di dalamnya (Rudini, 2017; Siddiq et al., 2020). Statistika dapat ditemukan pada dinamika sosial dan politik di Indonesia seperti Pemilu, Sensus Penduduk, dan penggambaran data demografi Indonesia (Mawan \& Amalia, 2015; Suhaidi et al., 2020; Sukherman, 2008). Pemilu yang telah diselenggarakan di Indonesia pasca reformasi baik pemilu Presiden, anggota legislatif, maupun pemilu Kepala Daerah semua menggunakan metode statistika dan menampilkan data statistika dalam prosesnya (Gunawan et al., 2018; Suhaidi et al., 2020). Dapat dilihat pada hari pemungutan suara bahwa hampir semua televisi dan media menampilkan hasil perhitungan cepat atau yang biasa disebut Quick Count. Proses Quick Count menunjukkan hasil perhitungan analisis sampel statistik dan menggunakan kaidah statistika serta harapannya dapat digunakan sebagai acuan untuk hasil perhitungan akhir, yang disebut Real Count (Andika et al., 2019; Hidayah, 2018). Perhitungan Quick Count 
juga dapat menunjukkan ke publik tentang bagaimana popularitas dan elektabilitas dari peserta pemilu tersebut (Mendoza \& Nieto-Barajas, 2016; Wibowo \& Darmanto, 2019). Selain Pemilu, pada kegiatan sensus penduduk juga mengkombinasikan antara nilai sosial dan statistika. Data statistika yang dihasilkan dari kegiatan sensus digunakan sebagai dasar kebijakan publik, karena data sensus menunjukkan kondisi sosial, ekonomi, dan informasi demografis dari suatu lokasi dan area, sehingga kebijakan - kebijakan publik tentu sudah semestinya mengacu pada informasi tersebut (Ibrahim et al., 2020; Numberi, 2020; Pitoyo \& Triwahyudi, 2018; Pitoyo \& Salisa, 2020; Rory \& Diana, 2020).

Penggunaan Statistika juga ditemui dalam dunia perkuliahan. Selain untuk digunakan oleh mahasiswa dalam riset dan skripsi, metode statistika juga digunakan oleh dosen dalam kegiatan asesmen dan peningkatan suatu proses pembelajaran (Hariyanti \& Wutsqa, 2020; Sukariasih et al., 2019; Yensy, 2020). Pada banyak program studi, mata kuliah Statistika juga merupakan mata kuliah pondasi untuk mata kuliah selanjutnya. Hal tersebut juga berlaku pada program studi Ilmu Pemerintahan Universitas Muhammadiyah Malang (UMM). Berdasarkan observasi, mahasiswa program studi Ilmu Pemerintahan UMM masih banyak yang kurang memahami materi dan masih kesulitan dalam mengaplikasikan metode statistika pada saat mereka menjalani proses skripsi. Hal tersebut dapat dilihat dari rasio mahasiswa mengulang yang cukup tinggi, yaitu hampir 20 persen dari total keseluruhan mahasiswa di angkatan tersebut dan mereka mengulang dikarenakan nilai mereka dianggap tidak memuaskan. Selain itu, berdasarkan data sekunder dari dosen mata kuliah Statistika Sosial juga diperoleh informasi bahwa kemampuan analisis interpretasi mahasiswa masih rendah. Berdasarkan masalah tersebut dan karena pentingnya mata kuliah Statistik pada Ilmu Pemerintahan, maka diperlukan metode pembelajaran yang dapat memaksimalkan pemahaman mahasiswa akan konsep dasar, teori, dan penggunaannya pada riset dan eksperimen. Salah satu pembelajaran yang dapat menumbuhkan keterampilan mahasiswa sembari meningkatkan pemahamannya adalah dengan model pembelajaran berbasis mini riset (Musa, 2020). Pembelajaran berbasis mini riset merupakan model pembelajaran project based learning dan model ini menggunakan kasus sebagai langkah awal dalam mengumpulkan dan mengolah informasi (Gani et al., 2020). Model ini diharapkan mampu membawa mahasiswa ke dalam suasana penelitian sesungguhnya dan semakin menajamkan pemahaman mahasiswa tentang interpretasi data dan aplikasi statistika.

Interpretasi matematis khususnya interpretasi data dan hasil penelitian adalah kemampuan penting yang harus dimiliki setiap peneliti. Dalam melakukan penelitian, seorang peneliti dituntut mampu menginterpretasikan dan menjelaskan seperti apa data yang dimiliki, karakteristiknya, pengolahan datanya, serta kesimpulan yang diperoleh dari hasil pengolahan data (Mustain, 2015). Pada hasil observasi, diperoleh informasi bahwa kemampuan interpretasi matematis mahasiswa Program Studi Ilmu Komunikasi umumnya sangar rendah, sehingga dengan digunakannya model pembelajaran mini riset, mahasiswa dituntut mampu menginterpretasikan masalah apa yang dimiliki dan lebih terampil dalam melakukan penelitian.

Adapun penelitian sejenis yang telah dilakukan sebelumnya lebih banyak membahas tentang pembelajaran berbasis riset di sekolah untuk meningkatkan minat belajar dengan pembelajaran yang inspiratif (Slameto, 2015; Widyasari, 2019), untuk menumbuhkan kemampuan berpikir kritis siswa (Arina et al., 2019; 
Fitriyah, 2020; Swandi, 2015; Wibowo, 2020), dan inovasi pembelajaran (Fadilla et al., 2019; Firmadani, 2017). Pada mahasiswa, pembelajaran berbasis riset digunakan untuk persiapan riset skripsi, peningkatan keterampilan meneliti, dan peningkatan pemahaman serta hasil belajar (Arumawan \& Yasri, 2021; Forijati, 2019; Haryati \& Firmadani, 2018; Irha, 2019; Junus \& Andula, 2020; Musa, 2020; Prahmana et al., 2016; Pratama, 2017; Trisna Amelia, 2020). Lebih lanjut lagi untuk pembelajaran statistika belum ada yang menggunakan model pembelajaran berbasis riset maupun mini riset. Sebelumnya yang digunakan pada pembelajaran statistika adalah berbasis IT (Aida, 2020; Sukariasih et al., 2019). Berdasarkan hal tersebut, penelitian ini akan memberikan informasi dalam kemampuan interpretasi mahasiswa pada mata kuliah Statistika Sosial menggunakan pembelajaran berbasis mini riset. Adapun tujuan penelitian ini adalah untuk mendeskripsikan kemampuan interpretasi mahasiswa dalam mini riset pada pembelajaran berbasis riset.

\section{METODE}

Penelitian ini menggunakan pendekatan deskriptif kualitatif. Populasi dan sampel dari penelitian ini adalah mahasiswa Ilmu Pemerintahan Universitas Muhammadiyah Malang yang sedang menempuh mata kuliah Statistika. Sampel dari penelitian ini diambil 1 mahasiswa yang melakukan proses mini riset. Teknik pengambilan sampel menggunakan purposive sampling, dengan pertimbangan mahasiswa yang mampu melakukan penugasan mini riset paling baik.

Langkah penelitian yang dilakukan meliputi observasi kelas, penugasan, dan analisis data. Penugasan yang diberikan kepada mahasiswa berupa pelaksanaan mini riset secara individu dan hasil mini riset mahasiswa tersebut akan dianalisis kemampuan interpretasinya. Adapun tahapan mini riset yang harus dilakukan mahasiswa adalah sebagai berikut:

1. Menentukan tema penelitian

2. Menentukan hipotesis penelitian

3. Menyebarkan angket online

4. Pengolahan data menggunakan Software SPSS

5. Mengolah data dan menginterpretasikan hasil penelitian

6. Pembuatan laporan

Aktifitas menginterpretasi hasil penelitian mahasiswa diukur berdasarkan indikator kemampuan interpretasi matematis mahasiswa yaitu memahami masalah yang diberikan, mengubah informasi dari masalah dalam bentuk cara lain yang telah direkam sendiri, dan menyimpulkan jawaban atau masalah yang sudah diberikan (Tabel 1). 
Tabel 1. Indikator interpretasi

\begin{tabular}{llll}
\hline No. & Aspek Interpretasi & Indikator: Mahasiswa dapat \\
\hline 1. & Memahami masalah yang telah diberikan & 1. & Mengerti arti simbol himpunan bilangan \\
& & 2. & Menuliskan simbol himpunan bilangan \\
& & dengan benar \\
& 3. & Menuliskan notasi himpunan dengan anggota \\
& & & - anggota himpunan yang benar \\
& 4. & Menjelaskan simbol himpunan bilangan \\
& & dengan benar \\
& 5. & Menyampaikan simbol yang digunakan \\
& & dalam bentuk himpunan \\
\hline 2. & Mengubah informasi dari masalah dalam & 1. & Menuliskan notasi dalam bentuk cara lain \\
& bentuk lain & 2. & Menafsirkan notasi dalam bentuk himpunan \\
& & 4. & Mengkomunikasikan simbol himpunan \\
& & & Menafsirkan jawaban dari masalah yang telah \\
& & nemuat simbol himpunan bilangan dan \\
& & notasi himpunan dengan bahasanya sendiri \\
\hline 3. & Menyimpulkan hasil dari masalah yang & Menuliskan kesimpulan dengan tepat \\
& diberikan & 2. & Menjelaskan hasilnya dengan efisien \\
\hline
\end{tabular}

\section{HASIL DAN PEMBAHASAN}

Melakukan penelitian kecil atau mini riset merupakan salah satu aspek dalam pembelajaran berbasis riset. Pada perkuliahan statistika, dosen meminta mahasiswa untuk melakukan penelitian kecil secara daring. Mahasiswa membuat tema penelitian, menentukan hipotesis, menyebarkan angket online, kemudian mengolah data angket menggunakan SPSS. Dalam mengolah data tersebut dan menyajikannnya dalam suatu bentuk laporan, mahasiswa melakukan beragam kemampuan, salah satunya adalah interpretasi matematis. Berikut merupakan hasil analisis interpretasi matematis satu subjek mahasiswa, disebut dengan subjek 1 . Subjek 1 dipilih berdasarkan kelengkapan proses yang telah dilakukan seluruh mahasiswa kelas Statistika Sosial.

Subjek 1 melakukan penelitian mengenai penggunaan kuota internet mahasiswa Program Studi Ilmu Pemerintahan pada masa Pandemi COVID-19. Latar belakang pemilihan judul tersebut telah dipaparkan dengan jelas, runtut dan rasional. Latar belakang memaparkan mengenai pandemi COVID-19 yang tengah melanda, serta sistem pembalajaran daring di Indonesia. Setelah latar belakang, subjek 1 menuliskan tujuan penelitian berdasarkan latar belakang yang dipaparkan. Tujuan penelitian yang dituliskan masih sedikit rancu, terdapat dua tujuan dalam satu kalimat. Namun, tujuan penelitian cukup sesuai dengan latar belakang yang dituliskan dalam laporan. Pada tujuan kedua, subjek 1 hendak mengetahui apakah penggunaan kuota pada masa pandemi ini masih dalam batas "wajar", namun belum didefinisikan secara operasional. Tulisan subjek 1 pada latar belakang dan tujuan menunjukkan subjek 1 telah memenuhi indikator 1 dari interpretasi matematis yaitu memiliki pemahaman terhadap permasalahan yang akan diteliti (Gambar 1). 


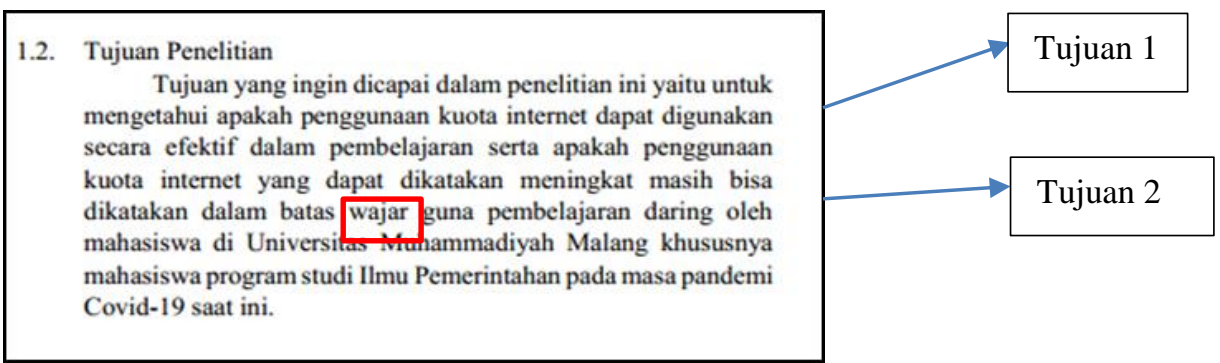

\section{Gambar 1. Tujuan penelitian subjek 1}

Berdasarkan permasalahan yang hendak diteliti, subjek 1 membuat angket sederhana mengenai penggunaan kuota selama masa pandemi. Kemudian subjek 1 menyusun data hasil angket dalam bentuk tabel (Gambar 2). Dalam menyajikan hasil angket dalam bentuk tabel, menandakan subjek 1 telah memenuhi indikator interpretasi matematis yang kedua yaitu mengubah masalah dalam bentuk lain. Terdapat dua kolom pada tabel, yaitu kolom nama dan kolom penggunaan kuota internet. Kolom penggunaan kuota internet yang akan dianalisis menggunakan SPSS.

\begin{tabular}{|l|c|}
\hline \multicolumn{1}{|c|}{ Nama Lengkap } & $\begin{array}{c}\text { Penggunaan kuota internet selama 1 bulan saat } \\
\text { pandemi / saat kuliah daring (contoh : 8GB) }\end{array}$ \\
\hline Vani Rizka Fatmala & 18 \\
\hline Anggreini Utami S & 13 \\
\hline Salvira Permanaputri & 11 \\
\hline Allysa Septya A & 19 \\
\hline Ahmad Lisyam Al Hilal & 12 \\
\hline Yastinki Hasni Ivani & 25 \\
\hline Rahmahdani Amin & 7 \\
\hline Delfigo Raven Anggrianto & 9 \\
\hline Sinarwati Putri & 58 \\
\hline Muhammad Fauzan Abdul J & 20 \\
\hline Putri Nabila & 50 \\
\hline Rezkv Maharani M & 16 \\
\hline
\end{tabular}

Gambar 2. Tabel hasil angket

Setelah membuat tabel hasil angket, subjek 1 kemudian membuat pertanyaan penelitian kembali. Pada pertanyaan penelitian yang kedua ini, subjek 1 membuat pertanyaan berbeda dengan tujuan penelitian di awal. Subjek 1 mengajukan pertanyaan untuk membandingkan antara penggunaan kuota "Vani" dengan penggunaan kuota teman sekelasnya. Dengan munculnya pertanyaan ini mengarahkan penelitian tidak lagi sesuai dengan judul, latar belakang dan tujuan. Pertanyaan ini menggiring penelitian hanya sebatas membandingkan penggunaan data Vani dengan teman sekelasnya saja (Gambar 3). Sehingga penelitian ini kehilangan esensinya untuk mengukur efektifitas pembelajaran daring dari segi penggunaan kuota internet. Munculnya pertanyaan ini menunjukkan kurangnya pemahaman subjek 1 mendefinisikan arti kata "efektif".

Setelah membuat pertanyaan penelitian subjek 1 merumuskan hipotesis, yaitu "H0: Penggunaan kuota Vani sama dengan mahasiswa lain, dan H1: penggunaan kuota Vani tidak sama dengan mahasiswa lain”. Hipotesis ini sedikit kurang spesifik. Melihat dari uji yang digunakan merupakan t-test. Dimana t-test dikhususkan untuk menguji perbedaan rata-rata. Sehingga subjek 1 masing kurang memenuhi dalam indikator mengubah informasi ke dalam bentuklain, khususnya deskriptor mengomunikasikan langkah penyelesaian permasalahan. 


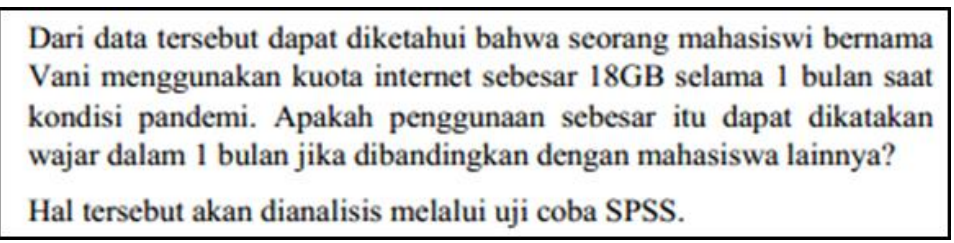

\section{Gambar 3. Pertanyaan penelitian subjek 1}

Dalam pengujian menggunakan SPSS, subjek 1 telah dengan tepat memilih uji sesuai dengan hipotesis yang dibuat. Yaitu menggunakan one sample $t$-test. Uji ini digunakan untuk membandingkan rata-rata sample dengan suatu nilai tertentu. Dalam penelitian S1, nilai tertentu yang dimaksud adalah penggunaan kuota Vani sebesar 18 GB. Pemilihan uji yang tepat ini diikuti dengan prosedur uji yang tepat pula. Gambar 4 merupakan screenshoot hasil olah data S1 menggunakan SPSS. Tabel yang muncul sudah berjudul one sample t-test. yang dianalisis juga tepat yaitu kolom tabel kuota. Test value yang digunakan $\mathrm{S} 1$ juga seudah sesuai yaitu 18. Di bawah tabel tertulis hasil perhitungan menggunakan fitur compute variable yang terdapat pada SPSS. Fungsi tersebut untuk memanggil nilai t-table yang nantinya akan digunakan untuk penarikan kesimpulan. S1 telah tepat memanggil t-table dengan memasukkan degree of freedom dan significancy yang tepat pula

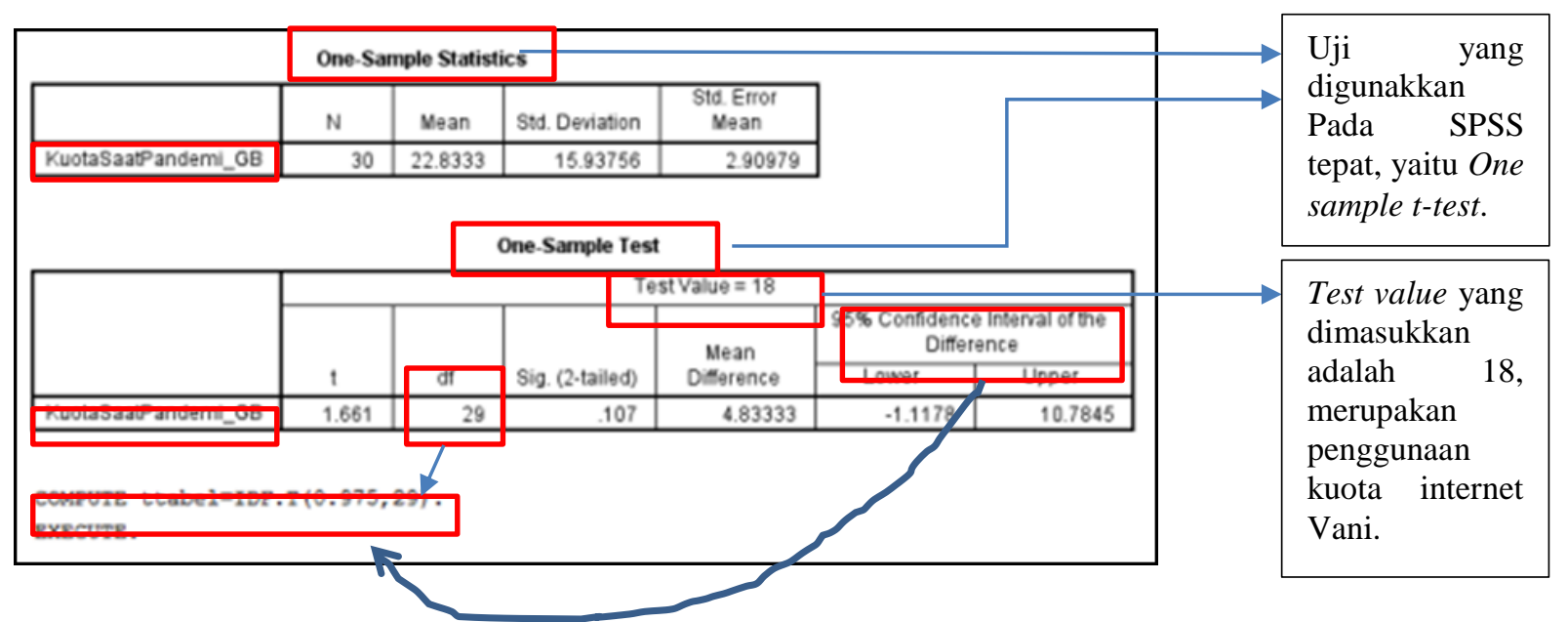

Gambar 4. Screenshot uji menggunakan SPSS

Setelah mengolah data menggunakan SPSS, subjek 1 menuliskan bagaimana ia mengambil keputusan. Keputusan yang diambil didasarkan pada ttabel dan t-hitung yang didapat pada SPSS, seperti pada gambar 5. Subjek 1 dengan tepat menentukan t-hitung sebesar 1,661 dan t-tabel yang didapat adalah 2,05. Namun, terlihat subjek 1 kembali belum memenuhi indikator mengubah informasi ke dalam bentuk lain, terutama pada deskriptor menuliskan notasi matematis. Subjek 1 telah menyatakan bahwa t-hitung berada di daerah penerimaan H0. Namun subjek 1 tidak menuliskan daerah penerimaan HO itu sendiri. Sehingga untuk orang awam yang membaca laporan mini riset ini akan tidak mengerti apa yang subjek 1 coba nyatakan mengenai hubungan daerah penerimaan $\mathrm{H} 0$, t-hitung dan t-tabel. Hal ini sejalan dengan penelitian terdahulu, bahwa masih ditemui mahasiswa yang mengalami kesulitan dalam menginterpretasikan ide penyelesaian 
dari suatu permasalahan (Ngedo et al., 2020; Sabirin, 2014; Zulkarnaen \& Kusumah, 2019).
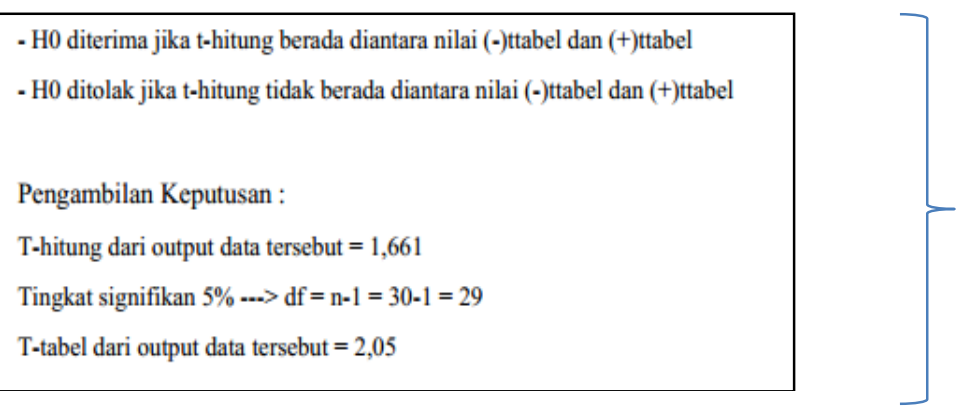

\section{Gambar 5. Pengambilan keputusan berdasarkan hasil SPSS}

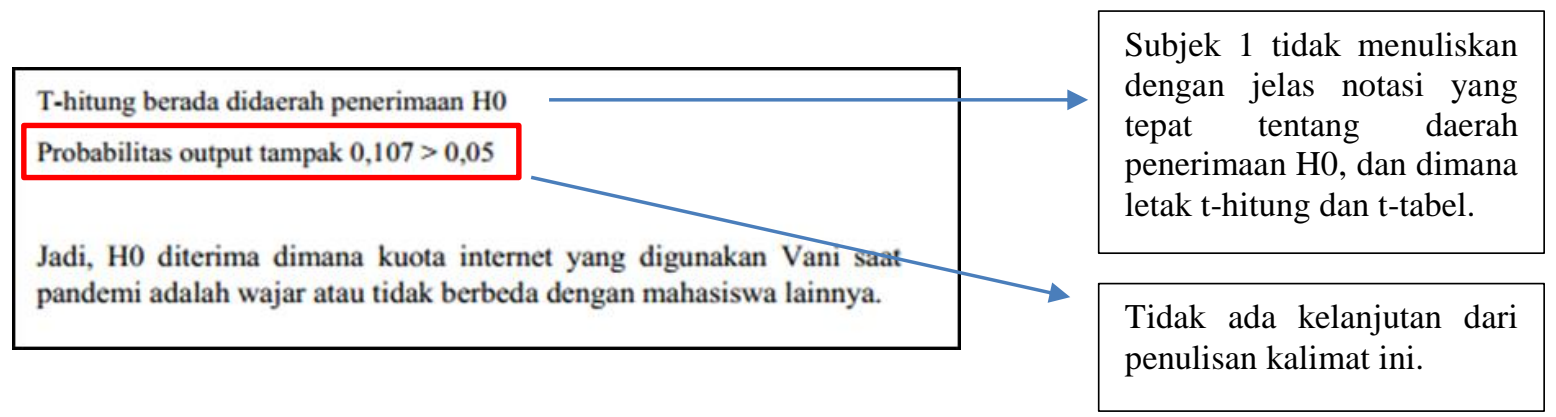

\section{Gambar 6. Pengambilan keputusan yang dilakukan subjek 1}

Selain menggunakan t-tabel dan t-hitung, subjek 1 terlihat menuliskan probilitas untuk pegambilan keputusan. Probabilitas yang didapat sudah sesuai yaitu 0,107 berdasarkan tabel one sample t-test. Namun kelanjutan dari penulisan probabilitas ini tidak dijelaskan lebih jauh. Sehingga akan lebih baik jika tidak dituliskan oleh subjek 1 .

Terakhir yang dilakukan subjek 1 adalah pengambilan keputusan. Masih pada gambar 5, subjek 1 telah berhasil menyimpulkan jawaban dari permasalahan yang ada (Gambar 6). Subjek 1 menuliskan kesimpulan dengan singkat, tanpa teori yang mendukung kesimpulan tersebut. Hal ini dikarenakan pemahaman konsep mahasiswa yang kurang mengenai materi penelitian (Arifin \& Herman, 2018; Radiusman, 2020; Subali et al., 2015).

\section{SIMPULAN}

Berdasarkan pemaparan hasil dan pembahasan di atas, penerapan pembelajaran berbasis riset pada matakuliah statistika membawa dampak positif pada kemampuan interpretasi matematis mahasiswa. Hal tersebut terlihat dari deskripsi pelaksanaan mini riset yang telah dilakukan mahasiswa dan diperoleh data ketercapaian indikator representasi matematis yang ditemukan pada mini riset yang dilakukan subjek 1 di kelas. Secara garis besar subjek 1 telah memenuhi ketiga indikator representasi matematis, yaitu memahami masalah, menyajikan masalah dan penyelesaiannya dalam bentuk lain, serta menyajikan kesimpulan dari permasalahan yang ada. Terdapat beberapa hal yang perlu ditingkatkan dalam mini riset yang dilakukan subjek 1, yaitu pada indikator menyajikan masalah dan 
penyelesaiannya dalam bentuk lain. Khususnya pada deskriptor menuliskan notasi dalam bentuk lain serta mengomunikasikan notasi sesuai dengan idenya.

\section{DAFTAR PUSTAKA}

Aida, N. (2020). Pengembangan Desain Pembelajaran Statistik Berbasis IT Menggunakan Pendekatan Realistic Matematics Education Untuk Mahasiswa Teknik Sipil. JPMI (Jurnal Pendidikan Matematika Indonesia), 5(1). https://doi.org/10.26737/jpmi.v5i1.1703

Andika, L. A., Azizah, P. A. N., \& Respatiwulan, R. (2019). Analisis Sentimen Masyarakat terhadap Hasil Quick Count Pemilihan Presiden Indonesia 2019 pada Media Sosial Twitter Menggunakan Metode Naive Bayes Classifier. Indonesian Journal of Applied Statistics, 2(1). https://doi.org/10.13057/ ijas.v2i1.29998

Arifin, F., \& Herman, T. (2018). Pengaruh Pembelajaran E-Learning Model Web Centric Course Terhadap Pemahaman Konsep Dan Kemandirian Belajar Matematika Siswa. Jurnal Pendidikan Matematika, 12(2).

Arina, H., Munawaroh, F., Rosidi, I., Hidayati, Y., Kunci, K., Pembelajaran, P., Riset, B., \& Kritis, K. B. (2019). Peningkatan Keterampilan Berpikir Kritis Siswa Melalui Pendekatan Pembelajaran Berbasis Riset. In Natural Science Education Research (Vol. 2, Issue 1). https://journal.trunojoyo.ac.id/nser/ article/view/4280

Arumawan, M. M., \& Yasri, H. L. (2021). Efektivitas Pembelajaran Berbasis Riset pada Mata Kuliah Hikmat al-Tasyri. Jurnal Penelitian Pendidikan Islam, 8(2). https://doi.org/10.36667/jppi.v8i2.484

Dewi, D. K., Khodijah, S. S., \& Zanthy, L. S. (2020). Analisis Kesulitan Matematik Siswa SMP pada Materi Statistika. Jurnal Cendekia: Jurnal Pendidikan Matematika, 4(1). https://doi.org/10.31004/cendekia.v4i1.148

Fadilla, I., Maharani, B., Usmeldi, U., \& Festiyed. (2019). Meta Analisis Pengembangan Bahan Ajar Berbasis Riset pada Pembelajaran IPA dan Fisika. Jurnal Penelitian Pembelajaran Fisika, 5(2).

Firmadani, F. (2017). Pembelajaran Berbasis Riset Sebagai Inovasi Pembelajaran. Prosiding TEP \& PDs, 4(14).

Firmansyah, M. A. (2017). Analisis Hambatan Belajar Mahasiswa Pada Mata Kuliah Statistika. Jurnal Penelitian Dan Pembelajaran Matematika, 10(2). https://doi.org/10.30870/jppm.v10i2.2036

Fitriyah, K. (2020). Profil Kemampuan Berpikir Kritis Siswa pada Mata Pelajaran Ekonomi Melalui Pembelajaran Berbasis Riset. Heritage, 1(1). https://doi.org/10.35719/hrtg.v1i1.6

Forijati. (2019). Model Pembelajaran Berbasis Riset Pada Mata Kuliah Ekonomi Mikro di Program Magister Pendidikan Ekonomi Pascasarjana Universitas Nusantara PGRI Kediri. Jurnal Pendidikan Ekonomi, 4(1).

Gani, A. R. F., Arwita, W., Syahraini, S., \& Daulay, N. K. (2020). Literasi Informasi Dalam Tugas Mini Riset Mahasiswa Baru Jurusan Biologi Pada Mata Kuliah Morfologi Tumbuhan. Jurnal Pelita Pendidikan, 8(3). https://doi.org/10.24114/jpp.v8i3.19809

Gunawan, M., Sumarno, -, \& Indrianawati, -. (2018). Pemetaan Psikografis Kependudukan Untuk Kepentingan Kampanye Pilkada (Studi Kasus: Kota Cimahi). REKA GEOMATIKA, 2016(2). https://doi.org/10.26760/jrg. v2016i2.1853 
Hariyanti, F., \& Wutsqa, D. U. (2020). Pengembangan perangkat pembelajaran statistika dan peluang untuk mengembangkan statistical literacy siswa SMP. Jurnal Riset Pendidikan Matematika, 7(1).

Haryati, S., \& Firmadani, F. (2018). Implementasi Pembelajaran Berbasis Riset (PBR) Dalam Mata Kuliah Psikologi Pendidikan. Indonesian Journal of Education and Learning, 1 .

Hidayah, N. (2018). Analisis Quick Count Metode Multistage Random Sampling dengan Estimasi Konfidensi Interval Menggunakan Metode Bayes (Studi Kasus: Quick Count Pemilihan Presiden 9 Juli 2014 oleh Lembaga Survei Indonesia). In Unnes Journal of Mathematics.

Ibrahim, D. I., Cahyadi, I., Anggriani, R., \& Abdurrahim, A. (2020). Pengaruh Motivasi dan Dukungan Keluarga terhadap Prestasi Belajar Mahasiswa Selama Penggunaan. Target: Jurnal Manajemen Dan Bisinis, 2(2).

Irha, N. T. U. (2019). Modifikasi IRC3 (Introduce, Review, Compare, Conclusion, Creative) Di IAI Al-Mawaddah Warrahmah Kolaka. Al-Hikmah, 13(1). https://doi.org/10.24260/al-hikmah.v13i1.1327

Junus, F. B., \& Andula, N. (2020). Pengaruh Implementasi Moodle dan Model Pembelajaran Kolaboratif pada Lingkungan Blended Learning terhadap Peningkatan Pemahaman Belajar Mahasiswa. Jurnal Teknologi Informasi Dan Ilmu Komputer, 7(4). https://doi.org/10.25126/jtiik.2020743289

Krisdiana, I. (2016). Pengembangan Perangkat Pembelajaran Pada Matakuliah Statistika Dasar Dengan Metode Problem Based Learning. Jurnal Edukasi Matematika Dan Sains, 4(1), 61. https://doi.org/10.25273/jems.v4i1.220

Kusrini, A., \& Novandalina, A. (2018). Faktor-Faktor yang Mempengaruhi Ekspor Karet Indonesia ke Malaysia Tahun 1983-2013. Economics Development Analysis Journal, 5(4). https://doi.org/10.15294/edaj.v5i4.22172

Maryati, S. (2018). Analisis Penawaran Tenaga Kerja Wanita Memiliki Balita di Perdesaan Sumatera Barat. Jurnal Ekonomi Pembangunan, 26(1). https://doi.org/10.14203/jep.26.1.2018.77-88

Mawan, A., \& Amalia, H. (2015). Statistika Demografi Riptortus linearis F. (Hemiptera: Alydidae) pada Kacang Panjang (Vigna sinensis L.). Jurnal Entomologi Indonesia, 8(1). https://doi.org/10.5994/jei.8.1.8

Mendoza, M., \& Nieto-Barajas, L. E. (2016). Quick counts in the Mexican presidential elections: A Bayesian approach. Electoral Studies, 43. https://doi.org/10.1016/j.electstud.2016.06.007

Musa, L. (2020). Implementasi Pembelajaran Berbasis Riset Untuk Meningkatkan Keterampilan Meneliti Mahasiswa. Tadrib, 6(1). https://doi.org/10.19109/ tadrib.v6i1.3786

Mustain, I. (2015). Kemampuan Membaca dan Interpretasi Grafik dan Data: Studi Kasus pada Siswa Kelas 8 SMPN. Scientiae Educatia, 5(2). www.syekhnurjati.ac.id

Ngedo, D. R., Prayitno, A.-, \& Octavianti, C. T. (2020). Representasi Dalam Pembelajaran Matematika Siswa Kelas Vii Materi Himpunan Smpk Wignya Mandala Tumpang. Pi: Mathematics Education Journal, 3(1), 38-46. https://doi.org/10.21067/pmej.v3i1.3675

Numan, M. (2019). Pengembangan Bahan Ajar Statistika Penelitian Pendidikan Matematika. Jurnal Mercumatika: Jurnal Penelitian Matematika Dan Pendidikan Matematika, 3(2). https://doi.org/10.26486/jm.v3i2.762

Numberi, H. Y. (2020). Tinjauan Pemanfaatan Data Sensus Harian Rawat Inap Di 
Rumah Sakit Umum Muhammadiyah Kabupaten Ponorogo. Jurnal Delima Harapan, 7(2), 73-85. https://doi.org/10.31935/delima.v7i2.98

Nurizzati, Y. (2014). Penempatan Strategis Mata Kuliah Statistika Pada Kurikulum IAIN Syekh Nurjati Cirebon. Eduma: Mathematics Education Learning and Teaching, 3(2). https://doi.org/10.24235/eduma.v3i2.54

Pitoyo, A. J., \& Triwahyudi, H. (2018). Dinamika Perkembangan Etnis di Indonesia dalam Konteks Persatuan Negara. Populasi, 25(1). https://doi.org/10.22146/ jp. 32416

Pitoyo, A. Z., \& Salisa, F. M. (2020). Aplikasi Sensus Harian Rawat Inap Berbasis Desktop Untuk Mempercepat Rekapitulasi Data Sensus Harian Rumah Sakit Xx Malang. Jurnal Manajemen Informasi Dan Administrasi Kesehatan (JMIAK), 3(01). https://doi.org/10.32585/jmiak.v3i01.678

Prahmana, R. C. I., Kusumah, Y. S., \& Darhim, D. (2016). Keterampilan Mahasiswa dalam Melakukan Penelitian Pendidikan Matematika melalui Pembelajaran Berbasis Riset. Beta Jurnal Tadris Matematika, 9(1). https://doi.org/10.20414/betajtm.v9i1.8

Pratama, A. B. (2017). Jurnal Ilmiah sebagai Bahan Pembelajaran Berbasis Riset pada Pendidikan Sarjana Administrasi Negara. Journal of Public Administration and Local Governance, 1(1).

Puspananda, D. R., \& Rahmawati, O. I. (2020). The influence of mathematics anxiety and emotional quotient on English language education students' statistics learning outcomes. Jurnal Math Educator Nusantara: Wahana Publikasi Karya Tulis Ilmiah Di Bidang Pendidikan Matematika, 6(2). https://doi.org/10.29407/jmen.v6i2.14836

Puspitasari, N. (2016). Kontribusi Matematika Terhadap Ilmu Komputer Di D3 Manajemen Informatika Politeknik Indonusa Surakarta. Jurnal INFORMA Politeknik Indonesia Surakarta, 3(2).

Radiusman, R. (2020). Studi literasi: pemahaman konsep siswa pada pembelajaran matematika. FIBONACCI: Jurnal Pendidikan Matematika Dan Matematika, 6(1).

Rizana, D. (2020). Pengaruh Kompensasi dan Pemberdayaan Terhadap Loyalitas Dengan Kepuasan Kerja Sebagai Variabel Intervening. Jurnal E-Bis (Ekonomi-Bisnis), 4(2). https://doi.org/10.37339/e-bis.v4i2.222

Rory, R., \& Diana, R. (2020). Prediksi Geostatistik Area Kecil Pada Data Survei Berbasis Blok Sensus. Seminar Nasional Official Statistics, 2019(1), 124-131. https://doi.org/10.34123/semnasoffstat.v2019i1.118

Rudini, R. (2017). Peranan Statistika Dalam Penelitian Sosial Kuantitatif. Jurnal SAINTEKOM, 6(2). https://doi.org/10.33020/saintekom.v6i2.13

Sabirin, M. (2014). Representasi dalam Pembelajaran Matematika. Jurnal Pendidikan Matematika, 1(2). https://doi.org/10.18592/jpm.v1i2.49

Sanusi, S. (2017). Analisa Kebutuhan Modul Ajar Statistika Industri Berbasis Proyek (Project- Based Learning). JURNAL INDUSTRI KREATIF (JIK), 1(01). https://doi.org/10.36352/jik.v1i01.52

Siddiq, I. H. Al, Sulistyo, W. D., \& Fibrianto, A. S. (2020). Pengembangan Kompetensi Penelitian Sosial Melalui Pelatihan Statistik Bagi Siswa Madrasah Aliyah Salafiyah Ketegan, Tanggulangin, Kab. Sidoarjo. Briliant: Jurnal Riset Dan Konseptual, 5(1). https://doi.org/10.28926/briliant.v5i1.369

Slameto, S. (2015). Pembelajaran Berbasis Riset Mewujudkan Pembelajaran Yang Inspiratif. Satya Widya, 31(2). https://doi.org/10.24246/j.sw.2015.v31.i2. 
p102-112

Sowanto, S., Mutmainnah, M., Saputra, H. A., \& Andang, A. (2019). Kemampuan Self-Efficacy Mahasiswa Melalui Bahan Ajar Metode Statistika Menggunakan Hybrid Learning Pada Tantangan Revolusi Industri 4.0. Supermat (Jurnal Pendidikan Matematika), 3(2), 65-73. https://doi.org/10.33627/sm.v3i2.245

Suandika, I. K. A., Nugraha, I. N. P., \& Dewi, L. J. E. (2020). Pengaruh Model Pembelajaran Kooperatif Tipe Team Game Tournament (TGT) Terhadap Keaktifan dan Hasil Belajar Pekerjaan Dasar Otomotif Siswa Kelas X TKRO SMK. Jurnal Pendidikan Teknik Mesin Undiksha, 8(2). https://doi.org/10.23887/jptm.v8i2.27599

Subali, B., Rusdiana, D., Firman, H., \& Kaniawati, I. (2015). Analisis Kemampuan Interpretasi Grafik Kinematika pada Mahasiswa Calon Guru Fisika. Prosiding Simposium Nasional Inovasi Dan Pembelajaran Sains 2015 (SNIPS 2015), 2015(Snips), 269-272.

Suhaidi, M., Nurhadi, N., \& Latip, L. (2020). Penerapan Framework Tonic Dalam Perancangan Aplikasi E-Concept Sebagai Alat Terukur Dalam Perekrutan Simpatisan Pilkada. Sebatik, 24(2). https://doi.org/10.46984/sebatik. v24i2.1135

Sukariasih, L., Saputra, I. G. P. E., Ikhsan, F. A., Sejati, A. E., \& Nisa, K. (2019). Improving the Learning Outcomes of Knowledge and Inquiry Skill Domain on Third Grade Students of Smp Negeri 14 Kendari Through the Guided Inquiry Learning Model Assisted By Science Kit. Geosfera Indonesia, 4(2), 175. https://doi.org/10.19184/geosi.v4i2.10097

Sukherman, M. (2008). Profil Pekerja Anak di Kabupaten Subang. Jurnal Kependudukan Padjadjaran, 10(2).

Sukmawati, D. (2018). Aplikasi Statistika Deskriptif. Jurnal Ilmu Tarbiyah Dan Ekonomi Syariah, 05.

Swandi, A. (2015). Pengaruh Metode Pembelajaran Berbasis Riset pada Materi Fluida Statis terhadap Hasil Belajar Fisika Kelas XI Madrasah Aliyah Madani Alauddin. Prosiding Pertemuan Ilmiah XXIX HFI Jateng \& DIY, Yogyakarta 25 April 2015, April.

Syafitri, E., \& Astuti, D. (2019). Workshop Penggunaan Spss Dalam Pembelajaran Statistika Teknik Pada Mahasiswa Teknik Mesin Dan Teknik Sipil Di Fakultas Teknik .... Jurnal Anadara Pengabdian Kepada ... http://jurnal.una.ac.id/ index.php/anadara/article/view/740

Syaviera Nova, A., \& Sastrawijaya, Y. (2017). Perancangan Implementasi ELearning Berbasis Moodle Dalam Matakuliah Statistika Program Studi Pendidikan Teknik Informatika Dan Komputer. PINTER : Jurnal Pendidikan Teknik Informatika Dan Komputer, 1(1). https://doi.org/10.21009/pinter.1.1.3

Trisna Amelia. (2020). Kemampuan Mahasiswa Dalam Pendefinisian Masalah Pada Pembelajaran Berbasis Riset. Perspektif Pendidikan Dan Keguruan, 11(2). https://doi.org/10.25299/perspektif.2020.vol11(2).5573

Wahyuningrum, A. S. (2021). Analisis Kesalahan Mahasiswa dalam Menyajikan Representasi Visual Data Statistik pada Mata Kuliah Biostatistika. 1(1), 3040.

Wells, D. D., \& Nemire, N. A. (2017). Introducing students to the application of statistics and investigative methods in political science. Teaching Statistics, 39(2). https://doi.org/10.1111/test.12124 
Wibowo, A., \& Darmanto, S. (2019). Impact of Quick Count Result of President Election on Stock Prices and Trade Activities in the Indonesian Capital Market. Saudi Journal of Business and Management Studies, 4(6).

Wibowo, B. A. (2020). Pelatihan Model Pembelajaran Sejarah Berbasis Riset Di Sman 1 Yogyakarta. INTEGRITAS: Jurnal Pengabdian, 4(2), 182. https://doi.org/10.36841/integritas.v4i2.550

Widyasari, E. (2019). Pembelajaran Berbasis Riset sebagai Upaya Peningkatan Minat Belajar Siswa terhadap Materi Perubahan Fisika Kimia. Indonesian Journal of Instructional Media and Model, 1(1). https://doi.org/10.32585/ ijimm.v1i1.313

Wikayanti, N. L. P. D., Aini, Q., \& Fitriyani, N. (2020). Pengaruh Kurs Dolar Amerika Serikat, Inflasi, dan Tingkat Suku Bunga Terhadap Indeks Harga Saham Gabungan Dengan Vector Error Correction. EIGEN MATHEMATICS JOURNAL, 1(2). https://doi.org/10.29303/emj.v1i2.58

Yensy, N. A. (2020). Efektifitas pembelajaran statistika matematika melalui media whatsapp group ditinjau dari hasil belajar mahasiswa (masa pandemik Covid 19). Jurnal Pendidikan Matematika Raflesia, 05(02).

Zulkarnaen, R., \& Kusumah, Y. S. (2019). Students' mathematical modeling abilities in interpretation-construction design model. Journal of Physics: Conference Series, 1318(1). https://doi.org/10.1088/1742-6596/1318/1/ 012097 